\title{
UNDERSTANDING «TRUST» IN THE PRACTICE OF AMIL ZAKAT ACCOUNTABILITY ORGANIZATION OF NURUL HAYAT
}

\author{
Agustinawati Vidya \\ Faculty of Economy and Bussiness, Airlangga University \\ E-mail: vidyaagustinawati@gmail.com
}

\begin{abstract}
Zakat, Infak, Sedekah (ZIS) management institutions as one way of balancing social economy with equal distribution of income but a crisis of confidence due to the lack of accountability practices through financial reporting and service-based Information Technology (IT) in modern era. The purpose of this study reveals how accountability practices can increase public awareness to fulfill Zakat, Infaq and Sedekah (ZIS) as well as to influence the behavior of ZIS managers in presenting reports on Zakat acceptance as a form of accountability and channeling their funds to achieve social welfare through the Education Scholarship Program. The method used is case study at Lembaga Amil Zakat Nasional Nurul Hayat Foundation, Surabaya. Sources of data in this study are primary data and secondary data. Data collection techniques are conducted by: 1) Direct Observation, 2) Interviews, and 3) Documentation. The analysis of data to be performed consists of description and content analysis. The collected data was then analyzed using descriptive method, with qualitative analysis. The first finding of this study is the practice of Accountability based on Islamic Sharia has brought consequences that the humanitarian aspect of zakat accounting, that is related to the implementation of moral ethical principles and God's law. Another finding obtained by researchers is on Zakat online payment system "ZakatKita". The management of ZIS Nurul Hayat has developed because this online system makes it easier for the muzakki, donators to do Zakat, Infak, Sedekah wherever they are and whenever want to do it.
\end{abstract}

\section{KEY WORDS}

Management, Amil Zakat organizations; accountability, practices; Zakat, Infaq, Sedekah.

The current economic conditions in Indonesia require people to work hard to fulfill their daily needs such as clothing, food and shelter rather than a decent level of education. Islam is one of the universal religious teachings that advocates the balance of socio-economic life (Dianto, 2014). This is realized in the mechanism of payment and distribution of Zakat which provides an illustration of how a religious pillar has the core of the spirit of income distribution for all regions (Harianto, 2016). According Htay \& Salman (2014) Zakat, infaq, sadaqah (ZIS) is part ofworship mahdah to God, but it is also aworship iztimaiyah Maliyah that has a variety of social functions are very strategic in order to improve the welfare and minimize poverty.

Islamic civilization in the era of globalization has many opportunities that have not been traced and have not been maximally utilized to overcome these problems. One of them is the management of zakat, infaq, alms (ZIS) which is mandatory based on accountability practices through financial reporting and information technology-based services (IT). In fact, many Amil Zakat institutions have emerged but have not implemented the practice of accountability and zakat services according to the current technological era. According to AlKhater \& Naser (2003) and Arli, Grace, Palmer, \& Pham (2017) this accountability practice is fundamental to the foundation of public trust in the reputation of the Organization. It is not hypocrisy, if the community (muzaki) based on the intention to pay zakat also requires an evidence of worship that can be channeled to those who deserve it (Masruki \& Shafii, 2013).

The author proves by presenting data on zakat potential in Indonesia as one of the countries with a majority Muslim population of 216.66 million inhabitants or $85 \%$ of the total population based on the 2015 Central Statistics Data (BPS). This fact implies that Indonesia has a large potential of zakat, infaq, and alms (ZIS). The total growth of ZIS fund collection 
during 2002-2015 reached $39.28 \%$ per year. The highest growth occurred between 2005 and 2007 (almost 100\%) due to the Aceh tsunami national disaster and the Yogyakarta earthquake. In the last decade, ZIS experienced rapid growth. However, this growth is still very far from the potential of zakat in Indonesia. The number of ZIS potentials inmember countries OIC (Organization of Islamic Cooperation) ranges between 1.8\% - 4.34\% of total GDP - Gross Domestic Product (Beik, 2015). If GDP is based on prices valid in 2015 amounting to Rp 11,531 trillion and Muslims in Indonesia as much as $85 \%$, the potential for ZIS ranges between Rp 176.42 trillion - Rp 425.38 trillion. Of the target, onlywas realized $2.09 \%$, amounting to $R p 3.7$ trillion $(0.03 \%$ of $G D P)$.

However, until now zakat funds from muzaki still dominate with a portion of $63.29 \%$, infaq / alms of $32.21 \%$, and other socio-religious funds of $4.31 \%$. The ZIS portion of individuals still shows significant numbers $(74.04 \%)$ and the body (company) the remaining $25.96 \%$. If we see the ZIS distribution in the social field occupying the top rank with a portion of $41.27 \%$, followed by education $20.35 \%$, economy $15.01 \%$, da'wah $14.87 \%$, and health $8.50 \%$. Although education is the second priority in the use of ZIS funds, currently the dropout rate is still quite high at $1,218,020$ or $3.06 \%$ of the total number of elementary school students up to secondary school. This is a motivation for the authors to take the topic of optimizing educational scholarship programs using ZIS funds based on public trust through accountability practices.

Various reasons were expressed as a response to the still low number of ZIS in Indonesia, including low public awareness and low trust in the ZIS management body. Rooted religious values should be a solution to overcome the two problems above. Communities tend to pay attention to corporate social responsibility when making judgment decisions about company image (Wagner \& Weitz, 2009; Wan \& Yu, 2016). In Nurul Hayat Surabaya Amil Zakat Foundation Foundation, Surabaya still does not use an accounting system in accordance with the PSAK that has been issued No. 109 concerning Accounting for Zakat because if without proper management such as accounting records with the principles stated in PSAK, an institution will have difficulty applying the principle of justice to parties those who have been involved well by the institution. The findings of this study are expected to be able to describe the practice of accountability in an organization by being able to implement and manage financial statements properly and transparently so as to increase public awareness, organizational reputation, and organizational achievement in presenting the overall Zakat acceptance report as a form of social welfare responsibility through education scholarship program (Arli, Grace, et al. 2017).

\section{THEORETICAL FRAMEWORK}

Zakat, Infaq, Shodakoh (ZIS) and Islamic Value. According to Zain, Darus, et al. (2014) the concept underlying Zakat, InfaQ and Shodaqoh (ZIS) is the concept of Tawhid, Caliph and Ukhuwah. The concept is a manifestation of Islamic values which is manifested in human relations to Allah SWT, human beings to the environment and humans to fellow humans (Yaya, 2004). The concept of Tawhid means accepting that God is the highest owner of everything on earth and in the universe and that humans are ultimately responsible to God. According to Zain, Darus et al. (2014) the belief that no human being is the same as God has given birth to the principle of equality of mankind. Islam represents $A d$-Din (way of life), humanity is expected to devote its life to God through worship as a religious ritual.

Underlying the Concept of Khalifah, Zain, Darus, et al (2014) states that humans as caliphs on earth need to uphold Sharia in their lives, maintain harmony and peace, protect the environment and fulfill tasks in the best way through advice, trust, truth and wisdom. Human relations with Allah SWT revolves around actions to devote his life through worship to Him. Human relations with other humans are based on the need to ensure that everyone lives in peace as well as the welfare of one another.

Based on the concept of Ukhuwah, Zain, Darus, et al. (2014) said that the relationship between humans and the environment is based on the agreement that the earth that has been lent to us will survive indefinitely. The concept of caliph (representative) refers to the 
role, status and also the responsibility of mankind towards themselves and society as a whole. Free to roam the earth, humanity has been entrusted with the responsibility to manage not only other humans but also other God's creations such as animals, plants and the environment.

Accountability Practices and the Meaning of the "Trust". National Amil Zakat Institution (Laznas) must hold the commitment of zakat autonomy which means by implementing a mandate metaphor that is realized with its concrete form, namely the zakat metaphor. The mandate metaphor in question is an allusion that is used to develop its organization in providing welfare to the community. The National Amil Zakat Institute (Laznas) is an organization that upholds its concern for the social community (Wahab \& Rahim Abdul Rahman, 2011).

Participants revealed that the National Zakat Institution (Laznas) which is engaged in the social field has the intention to be able to help many people to be useful. In this case, the National Zakat Institution (Laznas) has a universal soul that can boost its sense of care to help many people without any background differences, because every human being has the right to welfare (Saad, Aziz, \& Sawandi, 2014). Presentation of Sharia Financial Statements paragraph 25 that the principle of universalism can be essentially carried out for all interested parties regardless of ethnicity, religion, race and class.

According to Triyuwono Muhamad (2002), zakat is a bridge between human activities that are worldly and ukhrowi. Ummah funds are managed as a form of accountability to God (vertically) and stakeholders, especially donors (horizontally). Practice Accountability also serves as a counterweight between one's faith in Allah SWT and the belief in worship done to Humans. Accounting is information because the basis for making a decision in the organization because it can maintain the principle of justice in the community so that it can participate in ensuring its accuracy. Accounting is actually an Islamic teaching which is mandated to humans through their minds and minds and is part of muamalat Islam (Harahap \& Sofyan Syafri, 2004).

\section{METHODS OF RESEARCH}

The research method used is a qualitative method. The qualitative method is used in this study by conducting case studies with an interpretive approach as one of the methods used by the author to capture and describe a problem or phenomenon to understand the mandate and interpret the accountability practices in the Nurul Hayat Foundation Surabaya (Creswell, 2007). Data Collection Techniques are carried out by: 1) Direct Observation, namely by observing directly the zakat accounting process and the online system "ZakatKita" applied at LAZ Nasional Nurul Hayat Surabaya. This is done to find out exactly how the application of zakat accounting is applied so that it can increase the form of distribution of their funds through education scholarship programs. 2) Interview to obtain information directly about the LAZ National Nurul Hayat Surabaya situation by asking a few questions to the authorized employees in their respective tasks. 3) Documentation. Documentation is supported by books/catalogs on zakat and financial reports and administrative reports. The reason for choosing the Nurul Hayat Foundation (YNH) as the object of this study was because the authors sought and explored the existence of an increase in the performance and organizational performance of Amil Zakat based on the BAZNAZ (National Zakat Amir) award in 2017 with the best ZIS collection in Surabaya.

\section{RESULTS OF STUDY}

Nurul Hayat Foundation was established in 2001. At that time it was called the Panti Asuhan Social Foundation (YSPA) Nurul Hayat. The foundation was originally formed as a fundraiser Zakat, Infaq, Sodaqoh and suppliers CSR (Corporate Social Responsibility) PT. FIRDHA PRIMA where the company is engaged in traditional herbal medicine business based in Surabaya. 
In addition to PT CSR subsidies. Fridha Prima YSPA, they established an innovative business unit in Surabaya in 2002 in the form of a ready-to-serve Aqiqoh Business Unit. Seen the success of the month to month business experience an increase in profit surplus. From here YSPA Nurul Hayat developed a social program that is not only an orphanage and orphan scholarship.

Focusing on the mission of the social program, Nurul Hayat had to change a bigger costume. By law, on September 2, 2003, YSPA Nurul Hayat was dissolved and a new institution was established, called "Yayasan Nurul Hayat" and most of the fund raising was from the ummah's donations. This shows that Nurul Hayat is not an individual property but belongs to the ummah and is offered to the ummah.

Foundation'sYayasan Nurul Hayat Surabaya carried out fundraising through various funds including: zakat funds, general infaq shadaqah funds, humanitarian funds, waqf funds, management funds, and funds that are prohibited from shari'ah. The charity collected by Yayasan Nurul Hayat Surabaya comes from Surabaya residents and other regions, some donors come to submit their own funds to the Surabaya Branch of Nurul Hayat Foundation, some are asked to be picked up, and some are transferred through various banks including Bank Niaga, BII Syariah, Bank BNI Syariah, Syariah Mandiri, BCA, and Bank Muamalat.

There are three ways that are done, the most funds collected are funds that are directly picked up and come by themselves with a percentage of $60 \%$, picked up (the foundation picks up the party who will collect the zakat funds in the foundation. While those who give zakat will come directly directly to the foundation). While the funds that go through the bank are only about $10 \%-15 \%$, and the rest are funds from the Surabaya branch of Nurul Hayat Foundation, namely polyclinics, boutiques and shops.

Foundation Nurul Hayat Foundation is a social institution that applies sharia principles, but for its financial statements it still has not applied Islamic accounting because the accountants still do not understand it, as stated by participants regarding the introduction of Islamic accounting that is not yet understood. Accounting should be made to facilitate the users of financial statements and readers, even if it is a layman, because actually accounting is humanism that is able to neutralize humans, as revealed by (Triyuwono, 2010). Likewise with Islamic accounting that must be able to present financial statements transparently as a form of the realization of the mandate of a community fund management organization.

In the annual report in 2016 Nurul Hayat received donations amounting to Rp. $68,080,887,043$, the distribution of donations to Mustahik (those who were entitled to receive the zakat we paid) was Rp. $67,355,622,798(99 \%)$. This means that Nurul Hayat Foundation in 2016 succeeded independently where employee salaries were met from the profit of the business unit (not taking zakat, infaq and alms). In Figure 2 above, Nurul Hayat's financial report was recorded in the form of a diagram in January 2017. Unlike usual, which is dominated by zakat, at the beginning of the year the acquisition of ZIS funds was dominated by infaq. The Nurul Hayat Foundation accountability report is carried out through magazine publishing both in the form of hardcopy and presented on the website.

The financial statements made must be based on Islamic accounting principles, namely justice, truth and responsibility. The special principle in shari'ah accounting is the fast reporting, made by experts, firm, clear, and normative, has comprehensive information which can be addressed to all parties by being done in detail and thorough and not manipulated (Umah, 2011). Of all that will be used as a mandate, the aim is to maintain justice and truth, meaning that the principle emphasizes accountability so that no one involved is harmed by the trust given.

According to Nasrullah (2014) zakat accounting in accordance with PSAK No.109 aims to regulate the recognition, measurement, presentation and disclosure of zakat transactions, infaq, shodaqoh. Because recognition refers to the principle that governs when the transaction of revenue (revenue), expense (profit), profit (loss) and loss (loss) is recorded. Measurement also plays an important role in financial statements, namely the attributes used in measurement, this measurement aspect is almost no different from conventional accounting, because all attributes that will be used as references must consider theelements relevant, reliability, understandability, and comparability. 
For the presentation of sharia financial statements in accordance with PSAK No. 109, it is still not widely known because the regulation was recently made by the Financial Accounting Standards Board. Financial reports at the Nurul Hayat Foundation still have not provided financial statements in accordance with PSAK 109, because the accountants are still not familiar with PSAK 109. However, it would be better if the Nurul Hayat Foundation could apply the form of sharia financial statements in accordance with PSAK 109, namely, Balance Sheet, Earnings Report loss, cash flow statement, equity report, report on source and use of zakat funds, report on sources and use of policy funds, and notes to financial statements.

The characteristics of Yayasan Nurul Hayat Surabaya are organizations that have a mandate. Because what is mandated is the part recommended by the religion of Islam, the management is also according to the religion of Islam. Identification like this is important to set the accounting objectives of zakat so that the objectives are in line with the goals of the organization. Nurul Hayat Foundation periodically publishes financial reports to account for organizational performance during the period (Velayutham, 2014). Like most organizations, the report will be examined by an independent examiner to test the validity of the report while building and enhancing public trust. The Nurul Hayat Foundation Surabaya is a sharia organization that is in accordance with Islamic sharia which must be accounted for not merely worldly. Sharia opinion is important because it will show that the organization has carried out its mu'amalah activities in accordance with Islamic sharia which is one manifestation of organizational responsibility to Allah SWT.

ZIS Revenue Results in LAZ Nurul Hayat January-June 2016 seen from the total amount of $R p 2,054,276,616$ is very significant because at that time it coincided with the month of Ramadan which certainly many people want to do good deeds by doing alms, infaq and zakat. This was utilized by Nurul Hayat to increase ZIS fund revenues and utilize the ZIS funds as best as possible in accordance with the products owned by Nurul Hayat. Nurul Hayat has the application "ZakatKita" where the user of the application system "ZakatKita" for zakat payments in each month has an increase which if presented at $3 \%$, it is positive even though it cannot be said to increase maximally, because it shows an increase in its use, and more and more people are using this application and more and more are understanding it.

From the presentation of ZIS Laz Nurul Hayat's income for 4 months after the online application system of zakat payment in Laz Nurul Hayat, it can be seen that his opinion experienced a total increase both in the ZakatKita application and in the amount of income based on the table above shows there is an increase in users of the application system, especially in terms of payment of zakat. The conclusion that the online application system has a positive impact in the form of increasing ZIS income, in general and the increase in zakat included in the category of ZakatKita online system in Laz Nurul Hayat, and the increase in application users, this has an impact on Laz Nurul Hayat who is growing and known by the public in general.

From the explanation above, the online application is only provided for ZIS fund collection. There is no application that can be used to access information where the funds are distributed. If only by providing zakat payment applications online can increase the growth of ZIS funds by $4.6 \%$, what if the application is equipped with information on who our zakat recipients are, and we can choose the mustahik freely, even we can interact with the mustahik, it is not impossible, public trust will increase, which in turn will increase the volume of zakat receipts, so that social welfare will be realized.

This study also provides a view to optimizing the ZIS fund Education Scholarship Program by providing a recommendation system for recording (accounting) mustahik through online applications. Related recommendations given by researchers aim to make accountability practices better add zakat sources and funding reports (on PSAK 109 Accounting for Zakat, Infaq / Alms) at Yayasan Nurul Hayat Surabaya. Amil includes eight groups of ashnaf who are entitled to receive zakat funds. Although Amil has the right to receive zakat funds, it is better if the zakat funds received by Amil are distributed entirely for the benefit of the ummah and da'wah. Bring up additional information in the Financial Report, 
responsible for the flow of funds used for scholarships that cannot afford (consisting of information reports; student profiles, parents' profiles, and school profiles). For the online zakat payment system also requires socialization to people who do not understand the technology, and the need for security to secure the online zakat payment system.

\section{CONCLUSION}

Researchers conclude that trust in accountability practices carried out by Yayasan Nurul Hayat has fulfilled the principles of sharia which consist of benefit, universalism, balance and contain the values of transparency needed by the community. This can be seen from the financial statements of the Nurul Hayat Foundation made to be easily understood by many people and also presented transparently, able to balance the understanding of the community from various groups, backgrounds and levels of education. What is manifested in the practice of Accountability based on Islamic Shari'ah has brought the consequence that the humanitarian aspect of the accounting of zakat and infaq, namely matters related to the implementation of moral principles of God's ethics and law, such as virtue, truth, cannot be separated from the needs humans towards the values of accountability. The implication is that accountability practices on zakat, infaq, and alms (ZIS) accounting are able to stimulate the behavior of individuals around them to become individuals who are always doing transformation. Then the researcher found the online zakat payment system "Zakat Kita" where the management of ZIS Nurul Hayat developed because this online system made it easier for muzakki, donors to do zakat, infaq and alms wherever they were and whenever they wanted to.

The implication of this online zakat payment system is also a new breakthrough from the deepest potential of zakat payment and this has a good impact on the development of Nurul Hayat's ZIS Management. This online zakat payment system also regrets the development of technology at the moment, all of which are based on an easy and fast online. The limitation of this research is that not all zakat institutions are able to apply thoroughly what is revealed and recommended by researchers. At least the normative and simple accountability practices can be generalized.

\section{REFERENCES}

1. Al-Khater, K., \& Naser, K. (2003). Users' Perceptions of Corporate Social Responsibility And Accountability: Evidence From An Emerging Economy. Managerial Auditing Journal, 18(6/7), 538-548.

2. Arli, D., Grace, A., Palmer, J., \& Pham, C. (2017). Investigating The Direct And Indirect Effects Of Corporate Hypocrisy And Perceived Corporate Reputation On Consumers' Attitudes Toward The Company. Journal of Retailing And Consumer Services, 37, 139145.

3. Dianto, AM (2014). The Role of Baitul Maal Hidayatullah National Zakat Institution in Improving the Mustahiq Welfare of Tulungagung Regency. An-ratio: Economic Sharia Journal, 1(1), 138-160.

4. Harianto, S. (2016). Zakat Accounting On Income Critical Study Based On Government Regulation (Case Study In Aceh Province Of Indonesia). International Journal Of Business, Accounting And Management, 1(3), 47-52.

5. Htay, SNN, \& Salman, S. (2014). Proposed Best Practices Of Financial Information Disclosure For Alms Institutions: A Case Study Of Malaysia. World Applied Science Journal, 30(37), 288-294.

6. Masruki, R., \& Shafii, Z. (2013). The Development of Waqf Accounting In Enhancing Accountability. Middle-East Journal Of Scientific Research, 13(13), 1-6.

7. Nasrullah, N. (2014). The Influence of Human Resources Competence and Application of Accounting Standards for Zakat, Infaq and Alms (Psak No. 109) on the Quality of Financial Statements. 
8. Saad, RAJ, Aziz, NMA, \& Sawandi, N. (2014). Islamic Accountability Framework In The Zakat Funds Management. Procedia-Social And Behavioral Sciences, 164, 508-515.

9. Harahap, Sofyan Syafri, Islamic Accounting, Jakarta: Bumi Aksara, 2004, p. 143

10. Triyuwono, I., \& As' Udi, M. (2001). Sharia Accounting: Formulating Profit Concepts in the Context of Zakat Metaphors: Salemba Empat Publishers.

11. Umah, UK (2011). Application of Zakat Accounting at Amil Zakat Institutions (Study at LAZ DPU DT Semarang Branch). Value Added | Economic and Business Magazine, 7(2).

12. Velayutham, S. (2014). "Conventional" Accounting vs. "Islamic" Accounting: The Debate Revisited. Journal of Islamic Accounting And Business Research, 5(2), 126-141.

13. Wagner, T., Lutz, RJ, \& Weitz, BA (2013). Corporate Hypocrisy: Overcoming The Threat of Inconsistent Corporate Social Responsibility Perceptions.

14. Wahab, NA, \& Rahim Abdul Rahman, A. (2011). A Framework To Analyze The Efficiency And Governance Of Zakat Institutions. Journal of Islamic Accounting And Business Research, 2(1), 43-62.

15. Wan, LC, Poon, PS, \& Yu, C. (2016). Consumer Reactions To Corporate Social Responsibility Brands: The Role Of Face Concern. Journal of Consumer Marketing, 33(1), 52-60.

16. Yaya, R. (2004). Would The Objectives And Characteristics Of Islamic Accounting For Islamic Business Organizations Meet The Islamic Socio-Economic Objectives? Indonesian Journal of Accounting and Auditing, 8(2).

17. Zain, M., Darus, F., Yusoff, H., Amran, A., Fauzi, H., Purwanto, Y., \& Naim, D. (2014). Corporate Worship: An Islamic Perspective of Corporate Social Responsibility. MiddleEast Journal Of Scientific Research, 22(2), 225-232. 